\title{
ROLE OF ARCHITECTS AND LOCALNESS OF THE GLOBAL CITY: DISCUSSION OF OPERATIONALIZATION OF KEY THEORIES FOR UNDERSTANDING THE NOTIONS OF LOCALNESS IN BUILT FORM
}

\author{
Suneela Ahmed*
}

\begin{abstract}
This paper reviews at the urban and architectural case studies from India and Malaysia, where built form elements that highlight local advantage have been identified and articulated and have helped in cities to compete in the global paradigm. This paper analysis works of architects who have been labelled as Critical Regionalist architects from India and Malaysia. The objective is to tease out the design components addressed by these architects in their projects which connect to the local. The architects whose work has been addressed are Charles Correa and Balkrishna Doshi from India and Ken Yeang and Jimmy Lim from Malaysia. The analysis covers the following objectives:
\end{abstract}

a) To understand the design methodology and values of these designers and their contribution, if any, towards the development of localness in built form within their contexts.

b) To understand the scale at which each of the projects falls within different theoretical realms.

c) To analyse works of these designers with respect to the components that contribute to localness in built form and assess priority given to each of these components by the designers in their work.

This paper is part of an ongoing $\mathrm{PhD}$ research entitled ' $\mathrm{A}$ conceptual framework for evaluating localness through the design of built form: case of Karachi, Pakistan' being undertaken at Oxford Brookes University, UK. The research methodology for this paper is largely based on literature review and personal visits to the buildings in India.

Keywords: Localness, Global City, Globalization, Critical Regionalist

\section{INTRODUCTION}

All the architects reviewed are professionally trained people from the southern hemisphere and they started their practice when the modernist paradigm (1960-70) was in full swing. Many of them were influenced by the design philosophies of Architects from the west mainly Le-Corbusier and Louis Kahn.

Another aspect which these designers have in common is their practice in countries which experienced colonisation. They clearly understood the difference between colonisation and modernism and shunning the adaptation of the international style, which was the outcome of modernism, they opted for the sustainability paradigm which rejected commercialisation of the built form and opted for retaining localness. In the case of India this was supported by the policies of the then prime minister of India, Jawahar Lal Nehru (Belluardo, 1998) who encouraged the designers to come up with indigenous solutions which connected to the local context.

In colonialism, two cultures co-existed side by side and produced amalgamated built forms, but as an outcome of International style, modernism was dominating and eradicating indigenous cultures (Abel, 2000). Thus, these architects accepted colonialism as historical heritage of their countries, incorporating lessons learnt from the hybrid forms produced during colonial rule into their practice and rejected the international style, which was an outcome of modern movement and paid no respect to history of a place.

For the purpose of this paper localness of the built form has been defined as the incorporation of indigenous social and environmental values and processes into the built form within the contemporary global paradigm based on literature reviewed. The literature reviewed falls in three categories

* Suneela Ahmed, Assistant Professor, Department of Architecture and Planning, NED University of Engineering and Technology, Karachi.

Journal of Research in Architecture and Planning: Vol. 15, 2013 (Second Issue) - Architecture, Urban Design \& Planning 
and only a concise summary has been included here. The first group of literature is based on global cities where the local distinctiveness of the metropolis has been emphasized and the conclusions point towards the new metropolis being more local than the old one. These theories emphasise that globalness is a determinant of the local construct (Jencks, 2007; Sassen, 2001; Vale, 1992). The second set of the literature provides an overview of the theories that deal with the local distinctiveness of urban space and urban built form. These are theories of place making (Knox, 2011; Unwin, 2009; Watson and Bentley, 2007; Lynch, 1972; Alexander, 1977 and Jacobs, 1961), place identity (Relph,1976 and 1987), regionalism (King, 2004; Abel, 2000) and critical regionalism (Tzonis and Lefaivre, 2012; Frampton, 1983; Ricouer 1983). The theories on place identity and place have limited empirical application but they are useful in understanding the concept of the local and in resolving the contradictions between the global and the vernacular. The built form that is produced as an application of the theories of regionalism and critical regionalism is criticized as lacking the ability to change and evolve with time. The third sub section of the literature review summarises the theories on vernacular architecture (Asquith and Vellinga, 2006; Oliver, 1997) which highlight the lessons that can be learnt from the vernacular built form and its validity for the modern built form. According to the literature built form tries to connect to the local in theories of vernacular, place making, critical regionalism and regionalism. Each of these theories deal with different scale and typology of the built form. Theories on vernacular built form deal with the rural built form or form on the periphery of an urban settlement, theory on critical regionalism and regionalism are concerned with dominant architecture within a city where professional architects get involved. Theories on place making and place identity address neighbourhoods and the dialogue between built and open spaces within a defined block. Traditional architecture's emphasis is on different typologies of the built form but its connect to the present design profession is non existent and its stance is to revive the historical vocabulary of the built form. It does not necessarily promote innovation and modernism.

Based on the literature reviewed it is concluded that localness of built form has two aspects i) indigenous / vernacular, where pace of development is slow and is of adaptive nature with external influences being absorbed and created as part of tradition. ii) Secondly, cities in their aspiration to adopt a global image have to race against time thus they skip the phase of adoption and adapt an image. This adaption is influenced and modified by the local economy, technology and culture and what results is a hybrid built form. The question then is why are these choices made, and how do the key actors and agencies justify to themselves and to others in the development process and where does the idea of the traditional and local sit within this decision making milieu? These are some of the questions which are explored in this section with respect to works of Indian and Malaysian architect and the theories of global city, place making, place identity, regionalism, critical regionalism and vernacular.

\section{INDIAN ARCHITECTS: CHARLES CORREA AND BALKRISHNA DOSHI}

Works of two Indian architects, namely Charles Correa and Balkrishna Doshi have been analysed here to understand the design approach of these architects, their interpretation of the local and how dimensions of localness become indicators in their design approach. Their works have been looked at in response to local connection in terms of urban morphology, respect for natural resources, socially, economically and climatically responsive, incorporation of local materials, technology and crafts and flexibility.

In terms of larger theories their works have been looked at as Critical regionalist architects as they have been identified in the literature reviewed (Belluardo, 1998; Frampton, 1997; Curtis, 1987). Their design methodology towards place making and vernacular and traditional architecture is also addressed to understand their interpretation of localness in architecture and urban design.

Balkrishna Doshi, an Ahmedabad based Indian architect has overseen the execution of projects by both Le Corbusier and Louis Kahn in Ahmedabad, India. Charles Correa also started professional practice when Modernism was in full swing as a movement. With time modernism in architecture was criticized as insensitive to individuality of a region (Tzonis and Lefaivre, 2012 and Abel, 2000). One of its outcomes is the international style in which universal formulas were being applied to build form and places lost their individuality (Tzonis and Lefaivre, 2012 and Abel, 1986). Local architects of the sub-continent had to choose between adopting the international style or to manoeuvre it to respond to the local context. Doshi and Correa are two architects from India who having learnt the principles of International style tried to steer it in a direction where it responded to the local social, cultural and climatic requirements and yet remained progressive in its outlook. 


\section{The Urban Connection of the Built Form with a Critical Regionalist Approach}

Charles Correa, started his practice in 1958 in Mumbai, India. He has various architectural, urban design and urban planning projects to his credit. Correa's earlier works shows influences of Le Corbusier by use of striking concrete forms (Frampton, 1997). He advocates the viability of 'low-rise, high density housing as a normative form of ecological development' for the Indian context (Frampton, 1998: 11). This particular type of development, according to him, suits the social and economic requirement of majority of Indians who belong to the middle class, have joint family setups and have the requirement of incrementally developing their houses. In his urban design projects he respects the existing morphological setups and takes lead from precedence on ground. For instance, he has designed the Jawahar Kala
Kendra Museum in Jaipur India on 9 square mandala plan based on the precedence of the plan of the city of Jaipur which is also designed on a nine square mandala plan (see Figures 1-3). Thus the museum becomes a miniature representation of the city of Jaipur. Thus by learning from and respecting the urban morphology of a place Correa creates a local connection both in terms of concept and physicality (see Figures 4-5).

In an interview at the Royal Institute of British Architects, Correa stated in 2013 'We have all come too far away from the fundamentals,' says Correa. 'We have surrendered more and more to engineers, who manage to prop up any design and manage to heat and cool any kind of shape. Ultimately we are the losers: everything has left architecture, except whimsy and fashion.'

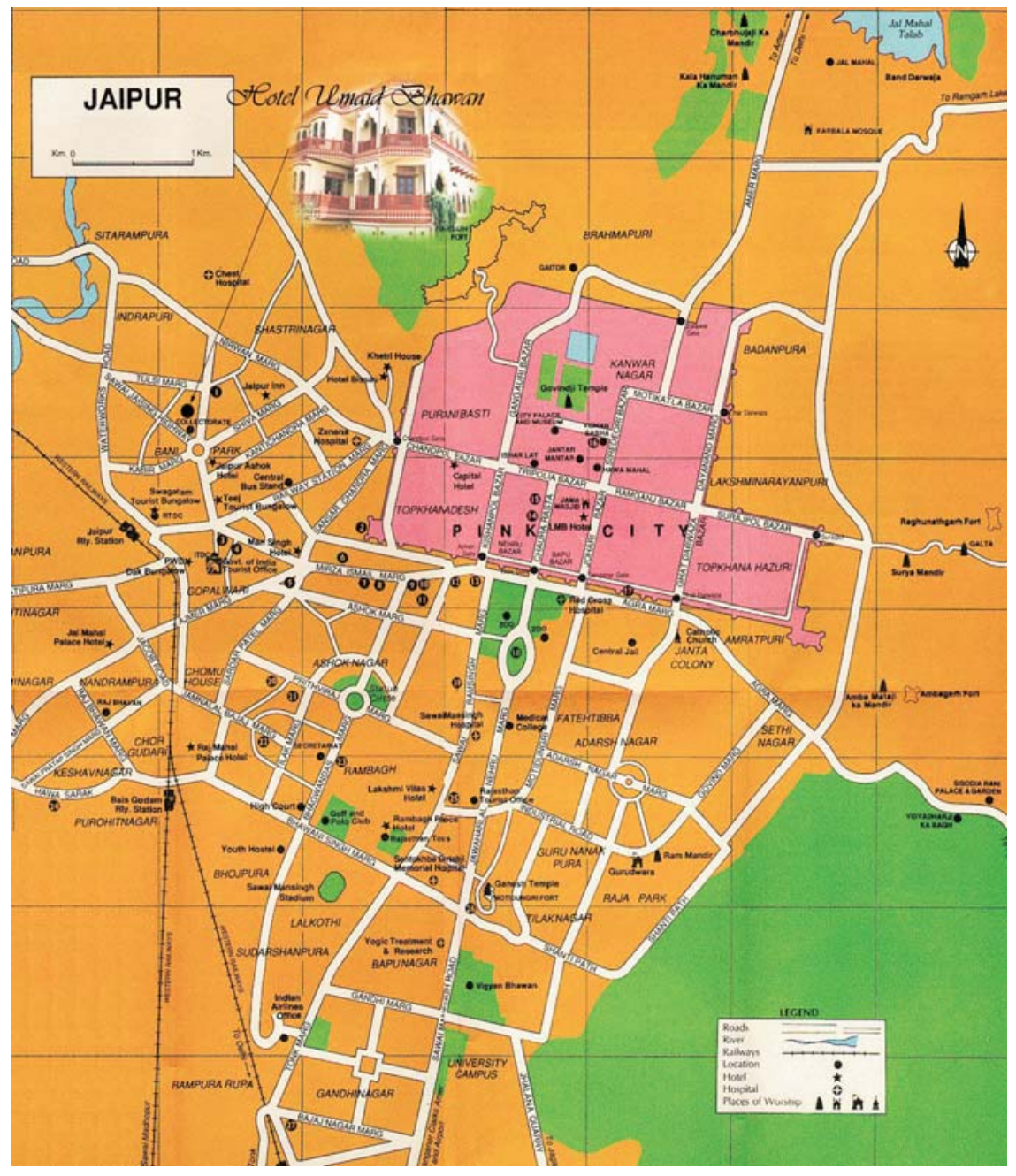

Figure 1: Map of Jaipur showing the 9 square original mandala plan

Source: http://www.jaipurpulse.com/2011/05/jaipur-city-road-map.html accessed 16-4-13 


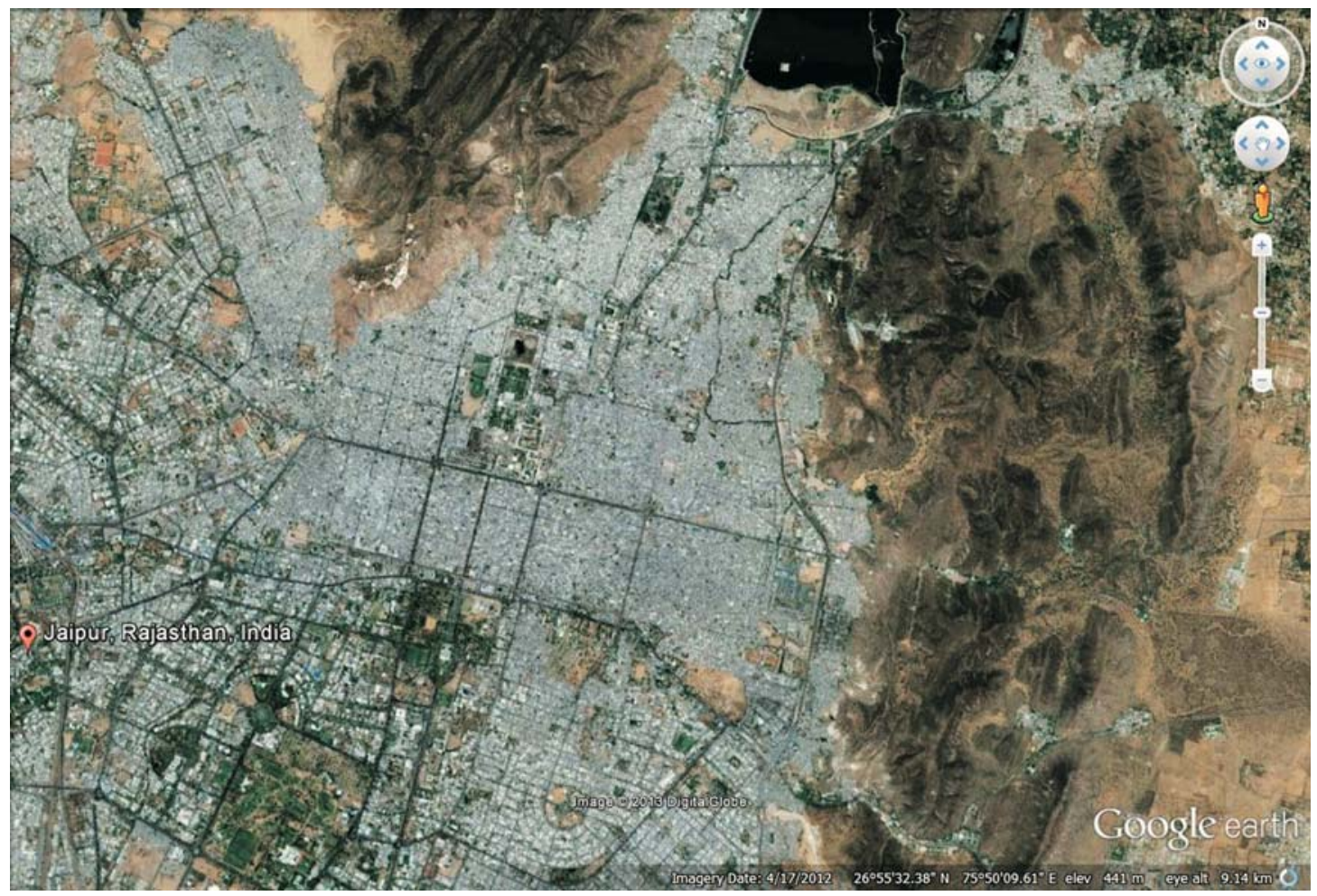

Figure 2: Google map of Jaipur, India- based on 9 square mandala plan Source: www.googlearth.com accessed 15-1-2014

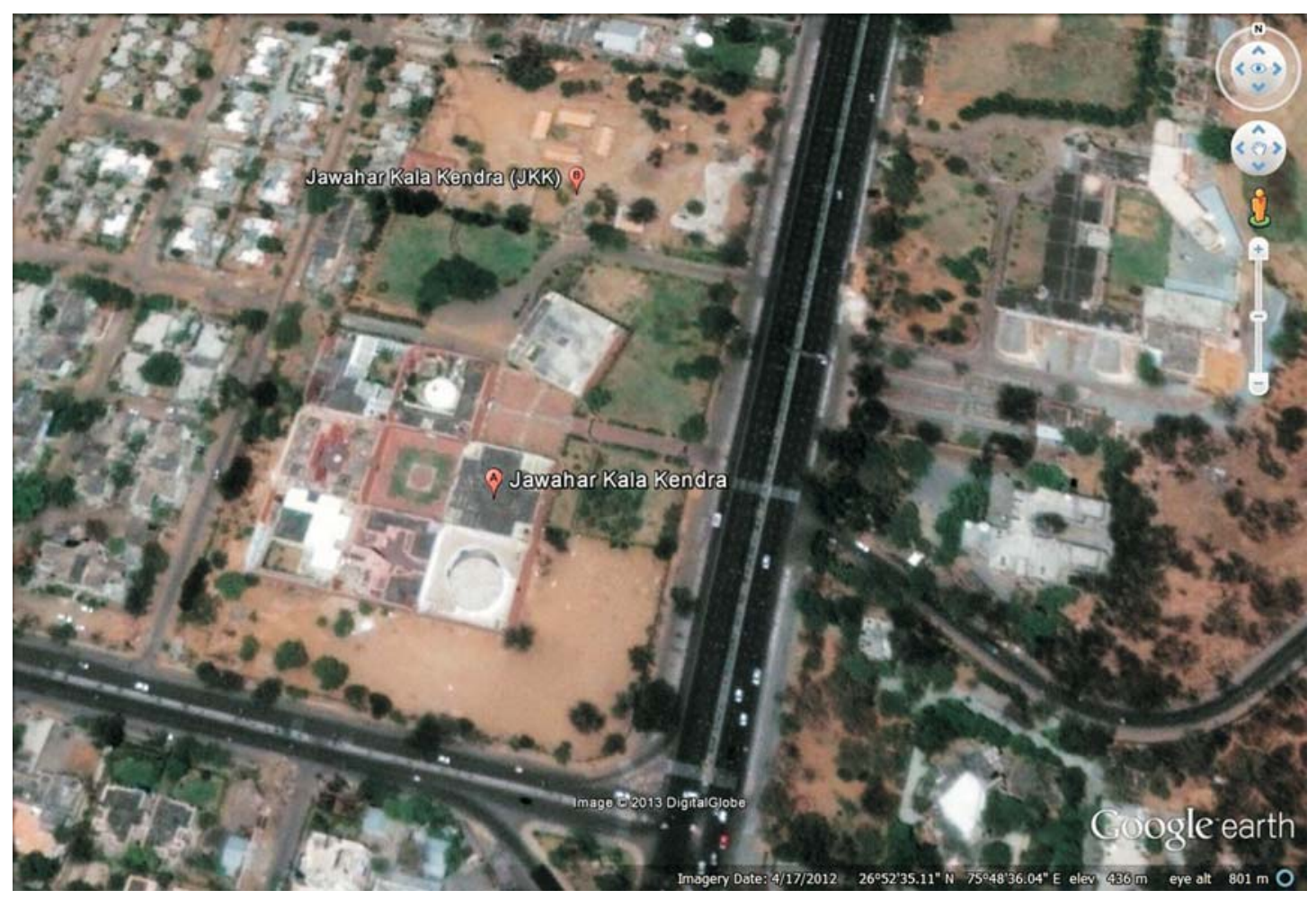

Figure 3: Google map of Jawaharkala Kendra Museum, Jaipur, India- based on 9 square mandala plan

Source: www.googlearth.com accessed 15-1-2014 


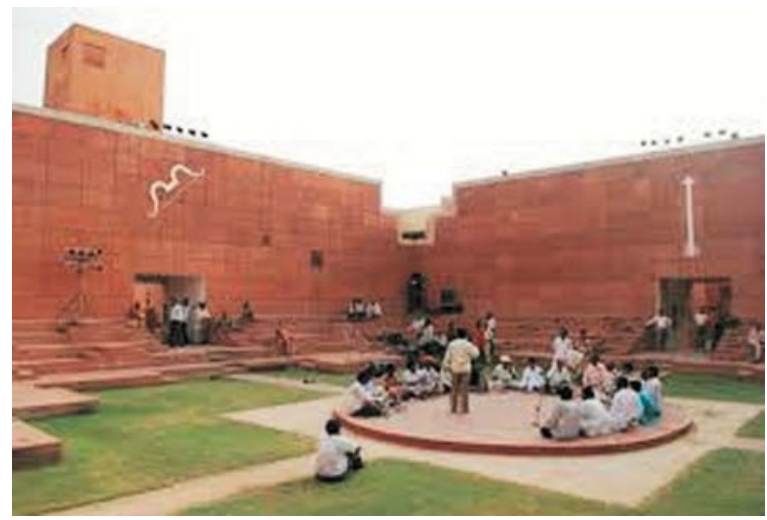

Figures 4-5: Views of Jawaharkala Kendra Museum, Jaipur, India Source: www.googleimages.com accessed 15-1-2014

He further adds 'making housing is like a bird building its nest,' says Correa. 'You start with a basic house, but you have to let people change it to their own needs.' Thus the concept of flexibility in the urban morphological evolution, according to Correa, becomes an important element of urban plan.

Balkrishna Doshi, started his own practice in Ahmedabad,
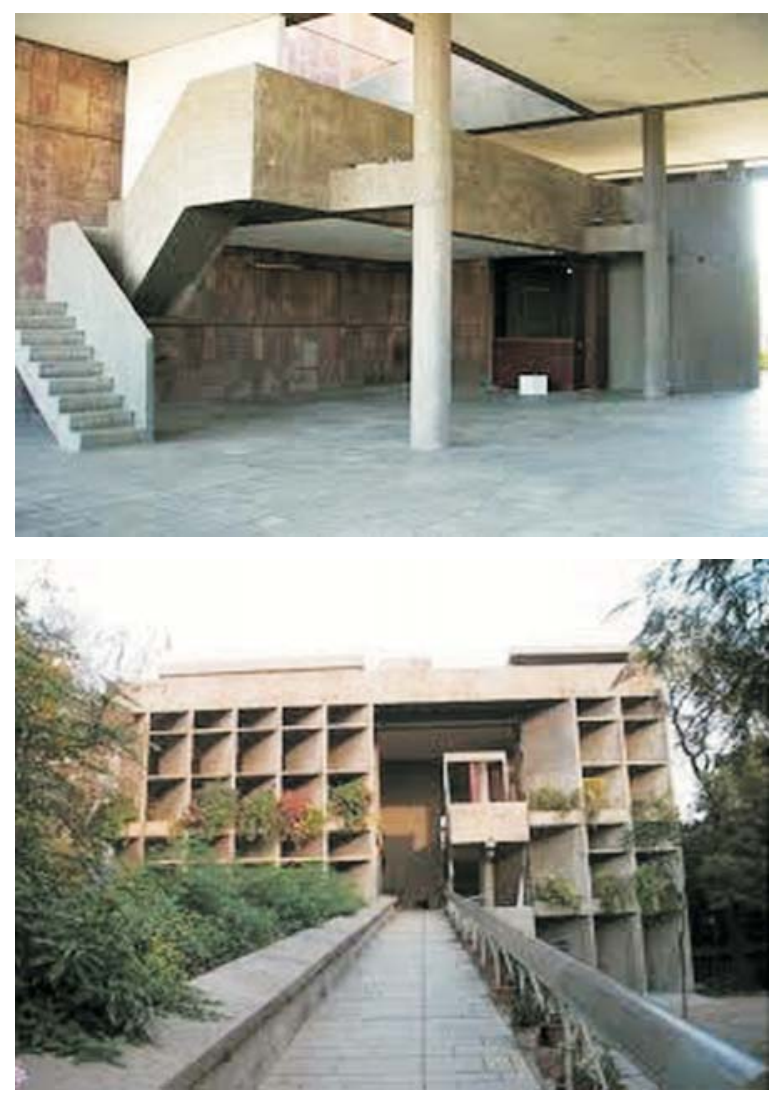

Figures 6-9: Images for Le Corbusier's Mill Owners Association building, Ahmedabad

Source: www.googleimages.com accessed 23-4-2013

Source: wWw.gogleimages.com accessed $23-4-2013$

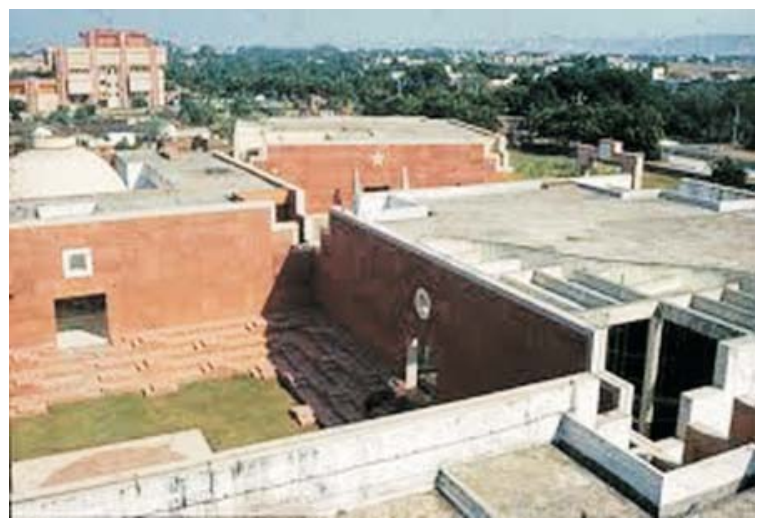

India in 1956 and has worked with the philosophy and application of combining prefabrication and local craft in the urban context. Early in his career Doshi interned at LeCorbusier's office for a period of four years and was later appointed as chief architect for execution of Le-Corbusier's projects in Chandigarh and later for Le-Corbusier's Mill Owners Association building in Ahmedabad (see Figures 6-13).
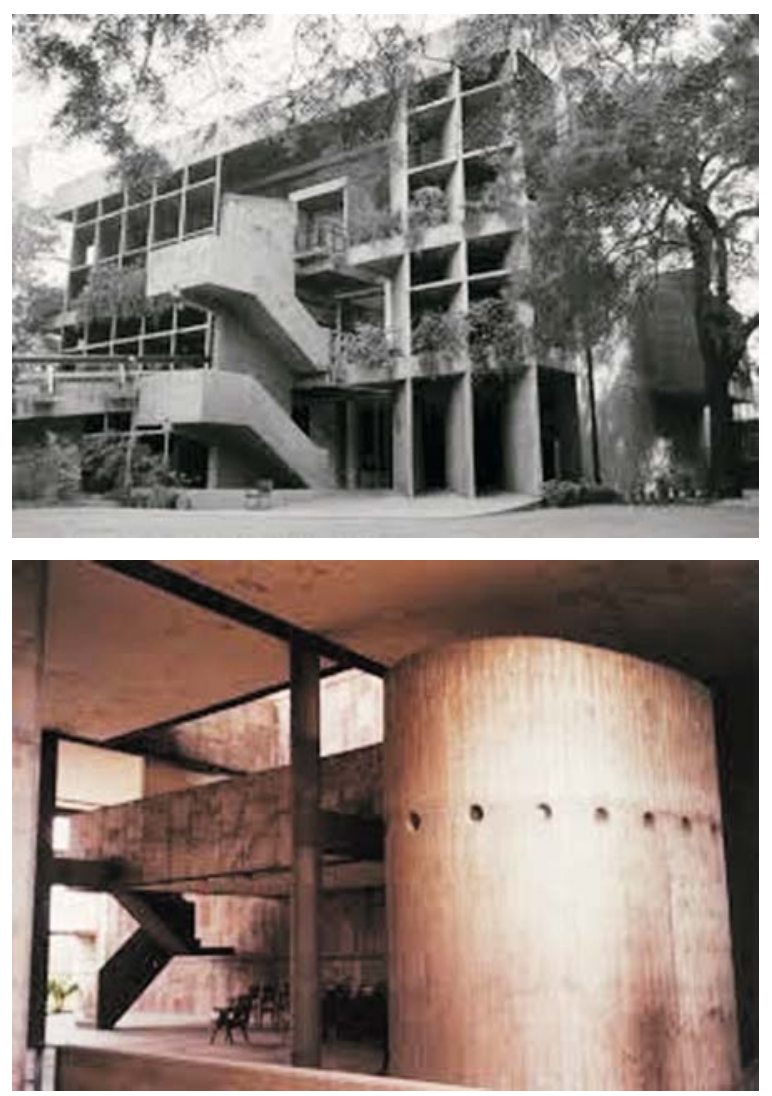

Journal of Research in Architecture and Planning: Vol. 15, 2013 (Second Issue) - Architecture, Urban Design \& Planning 

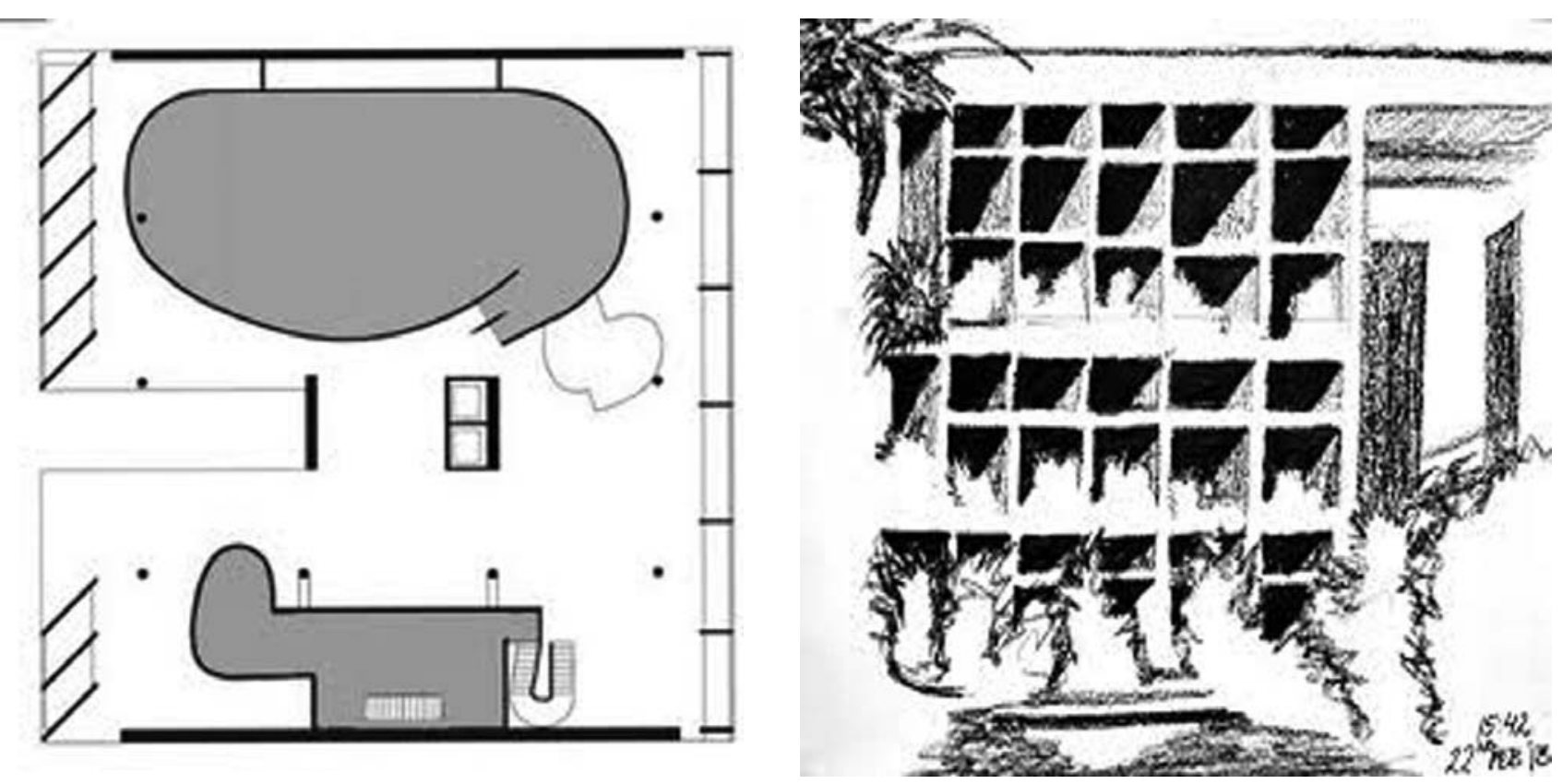

Figures 10-11: Images for Le Corbusier's Mill Owners Association building, Ahmedabad Source: www.googleimages.com accessed 23-4-2013

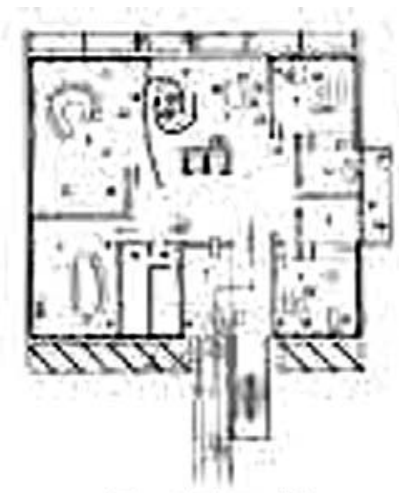

First Floor Plan

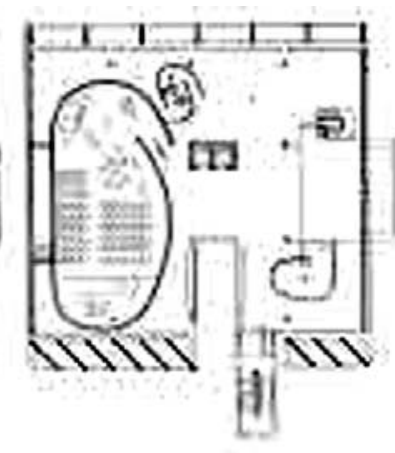

Second Floor Plan

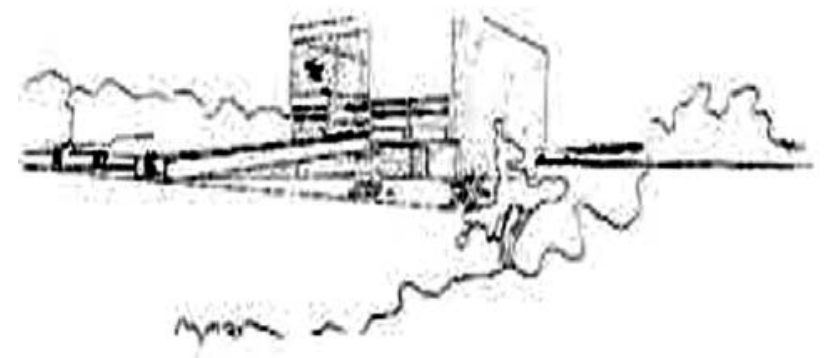

Sketch of MDA buildings by Corbusier

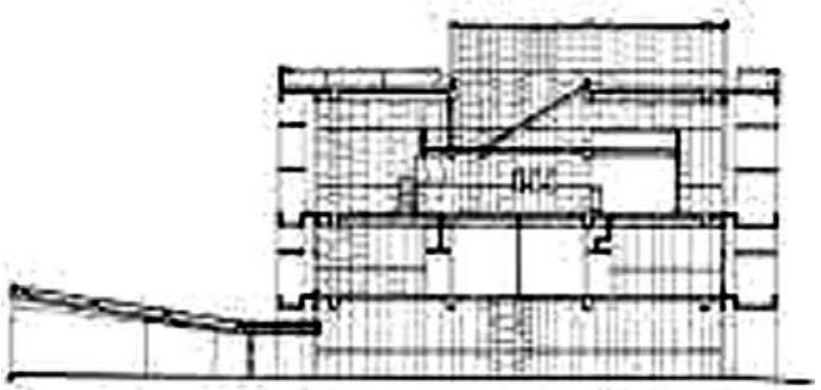

Figures 12-13: Images for Le Corbusier's Mill Owners Association building, Ahmedabad Source: www.googleimages.com accessed 23-4-2013 
He also worked with the idea of layers and overlays and organic geometry of urban spaces which in his view better full filled the social requirements of an Indian context rather than rigid planning (Curtis, 1987). In one of his earlier low cost housing projects in Ahmedabad for the Ahmedabad Textile Industry Research Association (see Figures 14-15) he used 'low brick vaults on parallel brick walls, a system that could be constructed by unskilled labour', scale and hierarchical gradation of a village, hierarchy of squares to be used as open spaces for socialising, medium sized vertical openings for ensuring flow of light and air and clear storey vaulted windows to avoid the glare at eye level and let the breeze through (Curtis, 1987: 15-16). He plays with the hierarchy of open, semi covered and covered spaces in most of his designs both at the urban and the architectural level and learning from the monument of Fathepur Sikri (see Figures 16-18) incorporates pergolas, pillared halls, terraces, pavilions and subtle shifting of axes and vistas in his designs. He is thus able to use an understanding of social linkages and connect them to physical form to achieve a local association on an urban level.
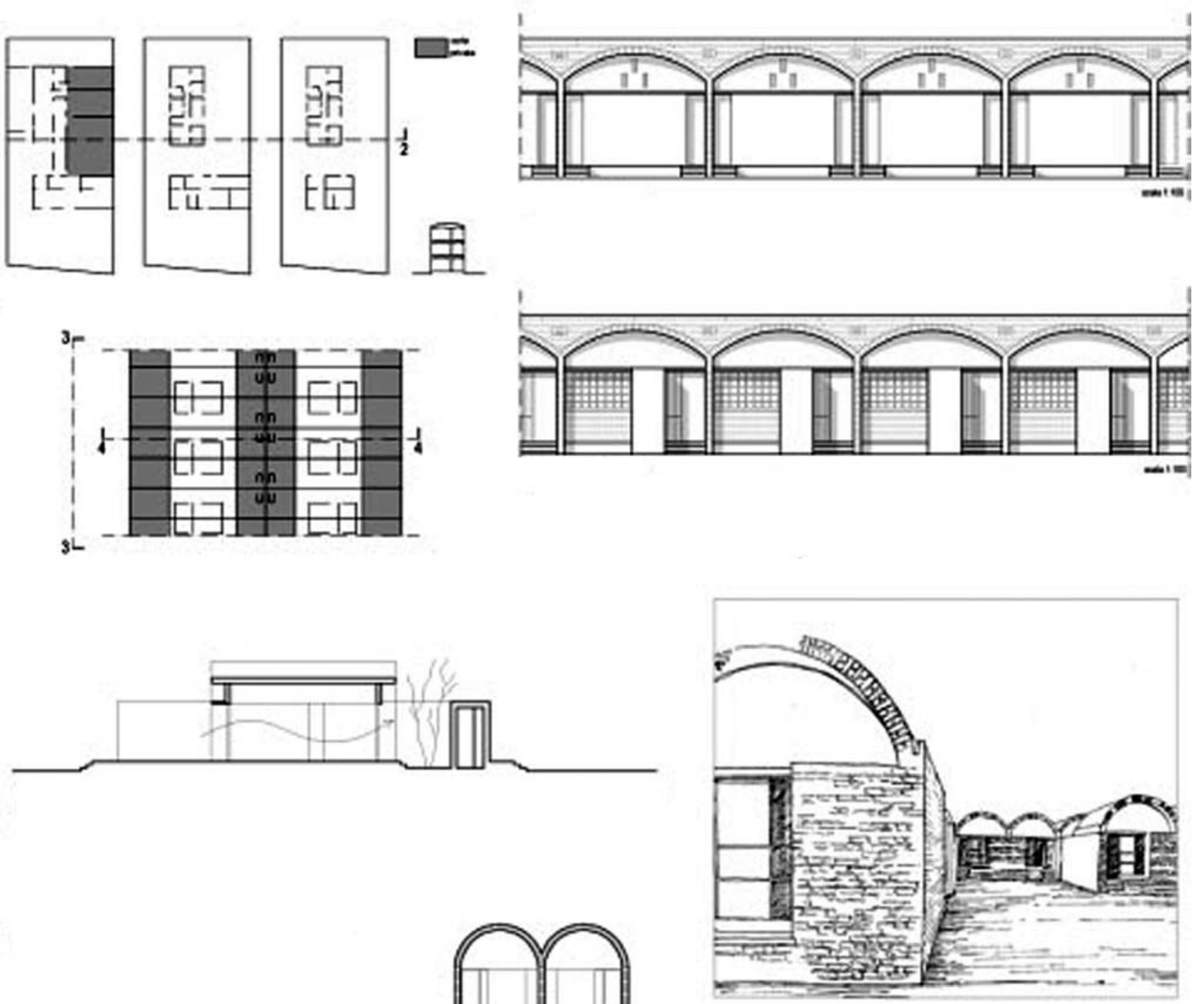

Figures 14-15: Housing for Ahmedabad Textile Industry Research Association

Source: http://identityhousing.wordpress.com/2009/12/04/balkrishna-doshi-atira-low-cost-housing-ahmedabad-1957-1960/accessed 16-4-13 

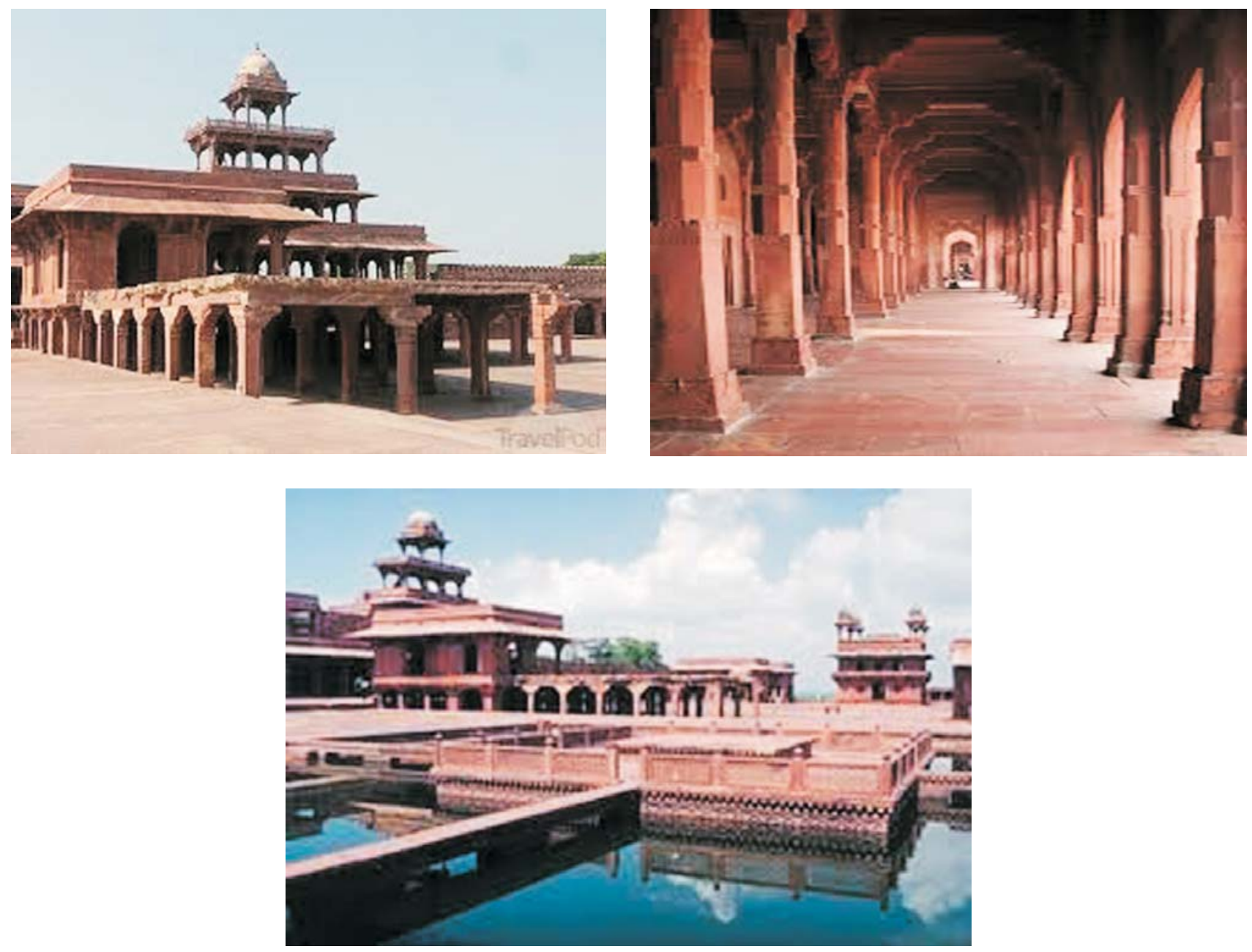

Figures 16-18: Images of FatehpurSikri, India

Source: www.googleimages.com accessed 16-4-13

\section{The Social Connection of the Built Form with a Place} Making Approach

In their mixed use housing designs both Correa and Doshi use courtyard typology of varying hierarchy. The circulation from the private space of the residence to the public squares is designed by these architects on principles based on traditional Indian cities, with shaded streets and steps and ledges along the streets to act as resting spaces (Curtis, 1988; Frampton, 1983). Correa and Doshi are also accredited to having designed housing schemes for urban areas that are low-rise and high density and allow for incremental development. These concepts have been executed by Correa in Hudco courtyard housing Jodhpur (1986) and Cablenagar township, Cota, Rajastan (1967) and by Doshi in Aryana low cost housing scheme, Indore (1982) (see Figures 22-
25), CIDCO mixed income mass housing, Kalamboli, (1988) and (2002). This housing module suits an Indian middle income household as the land is privately owned and the structure can be added onto to accommodate joint family setups (Frampton, 1997). Correa has also explored the possibility of incremental housing in low income settlements of India to cater for the economic constraint of low income residents as they cannot afford capital intensive houses and need to have the flexibility to add built structures incrementally. The incremental housing Belapur (see Figures 19-21), New Mumbai designed by Correa in 1983-86 is an example towards this end. It is spread over 136 acres and organised as low-rise structures around courtyards. The cluster planning has modules of 21 houses and three such clusters make a micro-neighbourhood (Chalana, 2010). 

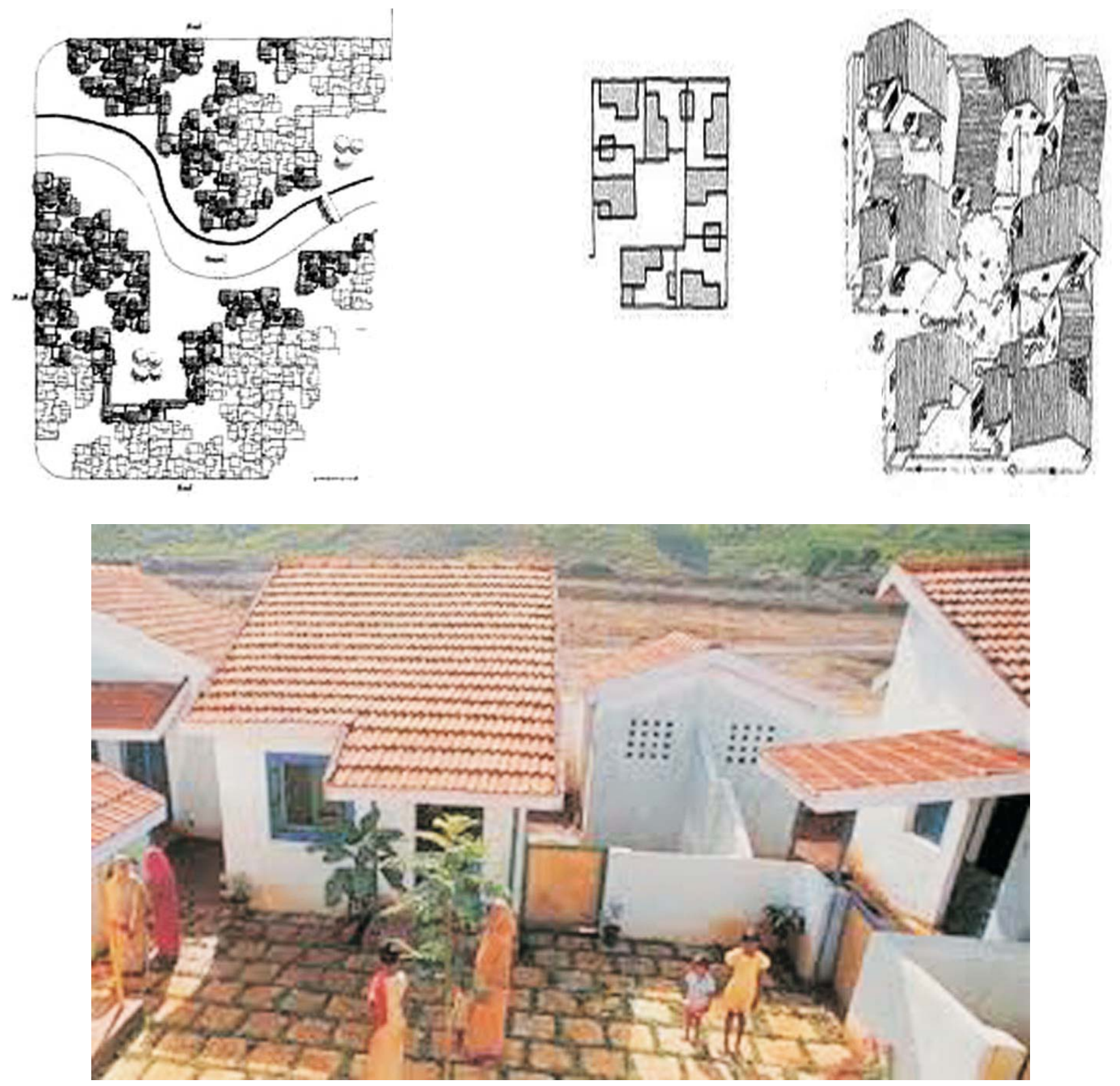

Figures 19-21: Plans and images of Belapur Housing, India Source: www.googleimages.com accessed 19-4-13

According to Chalana (2010) both Belapur and Aryana housing schemes designed by Correa and Doshi respectively reach densities of 500 to 650 people per hectare and have 2:3 open-built ratio. He proposes that design options should be developed with similar or higher densities for squatter settlements of Mumbai which currently have densities of

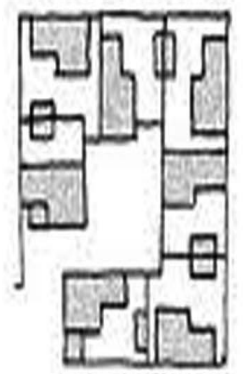



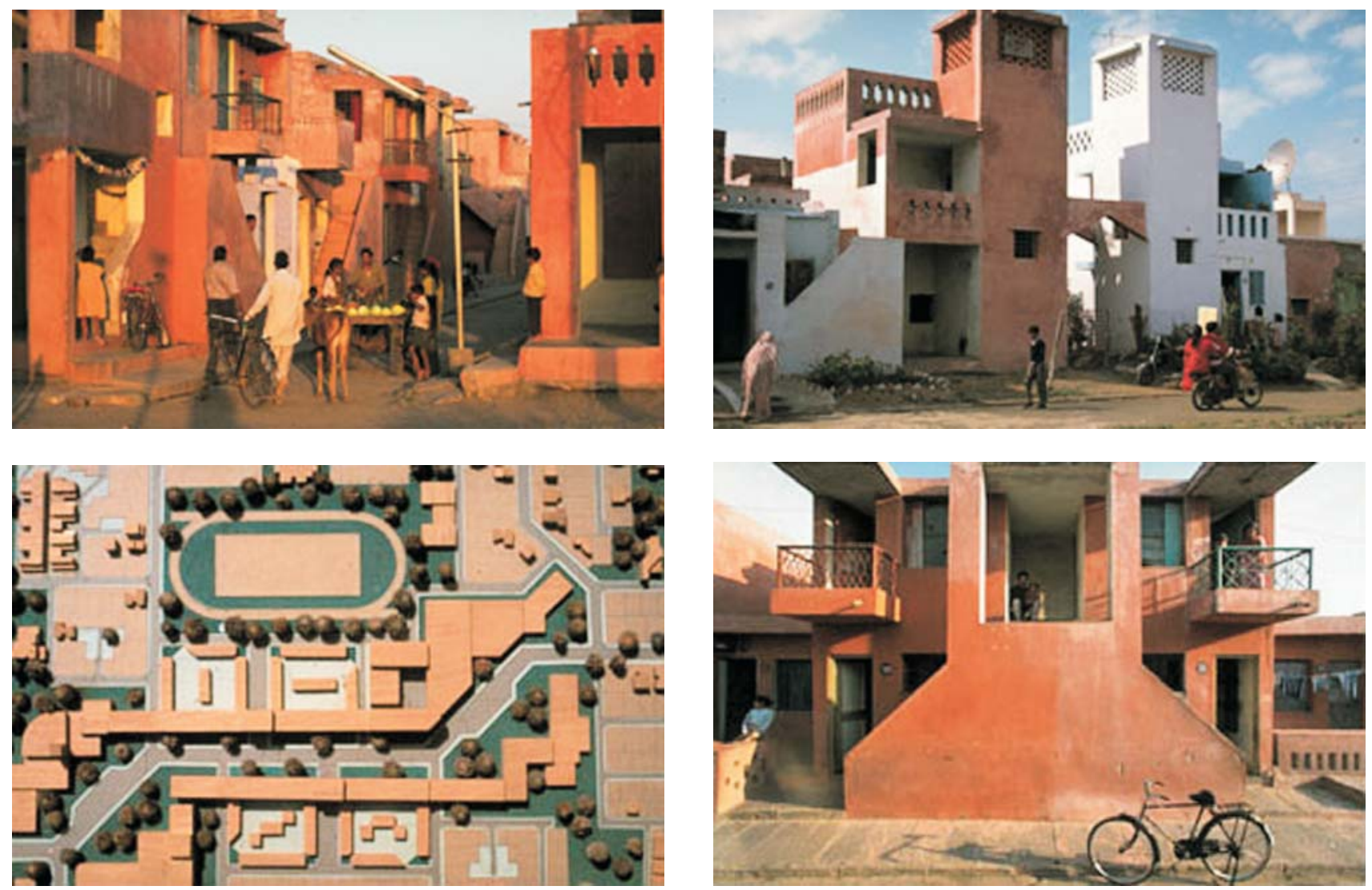

Figures 22-25: Plan and images of Aryana Housing, India

Source: http://www.akdn.org/architecture/pdf/1242_Ind.pdf.accessed 19-4-13

The Natural Connection of the Built Form with a Regionalist Approach

Doshi also explores the "mythical and poetic dimensions of nature, the flow of breeze and water, the contrast of light and shade, the relationship between ground and sky' (Curtis, 1988:10) in his designs. He uses the knowledge of vernacular and applies the principles in modern day society. For him the three ideas that help him achieve universality in design without losing regional charm are 'tradition, continuity, modern application' (Cutis, 1987:17)

According to Frampton (1997) for Charles Correa the understanding of the climate and social patterns of a context is a response to getting grasp of the identity of the region. His emphasis on the relationship between climate, social patterns and built form is what dictates his design career. He defines 'identity' as a process and not a 'found' object. According to him 'it can be likened to the trail left by civilisation as it moves through history' (Correa, 1983:10). He further goes on to explain that 'identity' cannot be invented and is not a self-conscious thing. It needs to be sifted out through our understanding of the reality which in the case of India is based on understanding of four essential things: living patterns, designing of energy-passive buildings, urbanisation and the nature of change. Climate according to him is the 'crucial determinant in this process' as climate not only dictates the requirements of the built form but also the 'patterns of culture and rituals' (Correa, 1983:10). Based on his understanding of the local climate Correa worked with variations on two themes:

a) The tube house which is long and narrow with small openings in the windward direction and larger openings in the leeward direction to maintain a constant draft (see Figures 26-29).

b) Open to sky spaces which could be a courtyard, a balcony, a veranda, platform, roof terrace, landing on a stair case, a communal space and so on. The open to sky spaces were the main areas to be designed and the built form could follow the lead- as he understood that 
these forms were the best response to the climate and social activities of India. He expresses the metaphysical aspects of the sky though incorporation of the 9 square mandala plan in his later designs- with the 9 squares having spiritual and ritual significance in Hinduism (as seen in the Jawaharkala Kendra museum, Jaipur).

According to the interview of Correa conducted at Royal Institute of British Architects, London in June 2013 successful buildings must be tied to their context. Correa states 'Architecture is not a moveable feast, like music, you can give the same concert in three different places, but you can't just repeat buildings and clone them across the world.' Thus the connect of the building to the immediate context in terms of its climatic response is important in Correa's practice. It is for this reason that he is not willing to call himself an international architect as 'he refuses to get off a plane and design' (RIBA, 2013).

Balkrishna Doshi also stresses on designing passively ventilated buildings. His apprenticeship with Le-Corbusier in his early career and execution Le-Corbusier's designs in Chandigarh, India taught him how to incorporate natural ventilation in his designs (Curtis, 1987). At the time that Doshi interned at Le-Corbusier's office- buildings like Ronchamp (see Figures 30-31), La Tourette (see Figure 32), the Jauol House (see Figures 33-34) and the Indian buildings of Chandigarh were being designed for where Le-Corbusier used rough concrete and brick and designed around capturing light (Curtis, 1987). Doshi also learnt the art of designing for and around light from Le Corbusier and applied and adopted it in the context of India in the design of Indian Institute of Management (see Figures 35-36), Bangalore, India by Doshi in India.

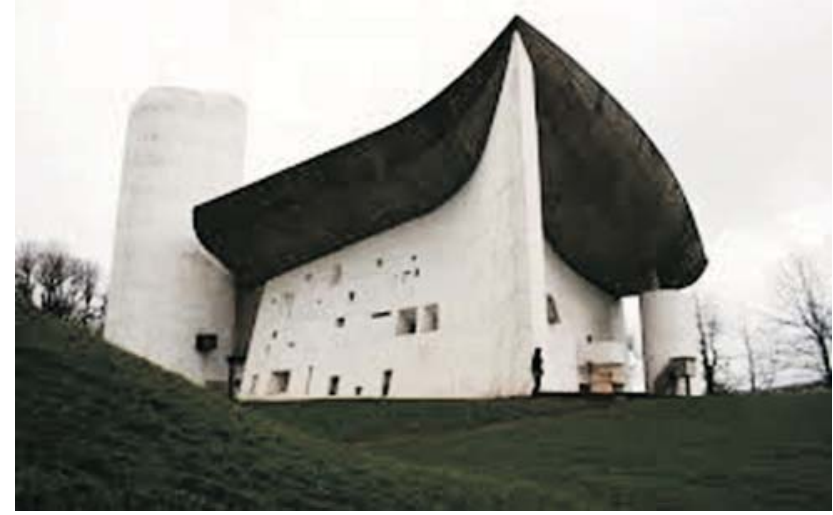

Figure 30: Ronchamp, France by Le-Corbusier

Source: wwww.googlegeimages.com accessed 23-4-13
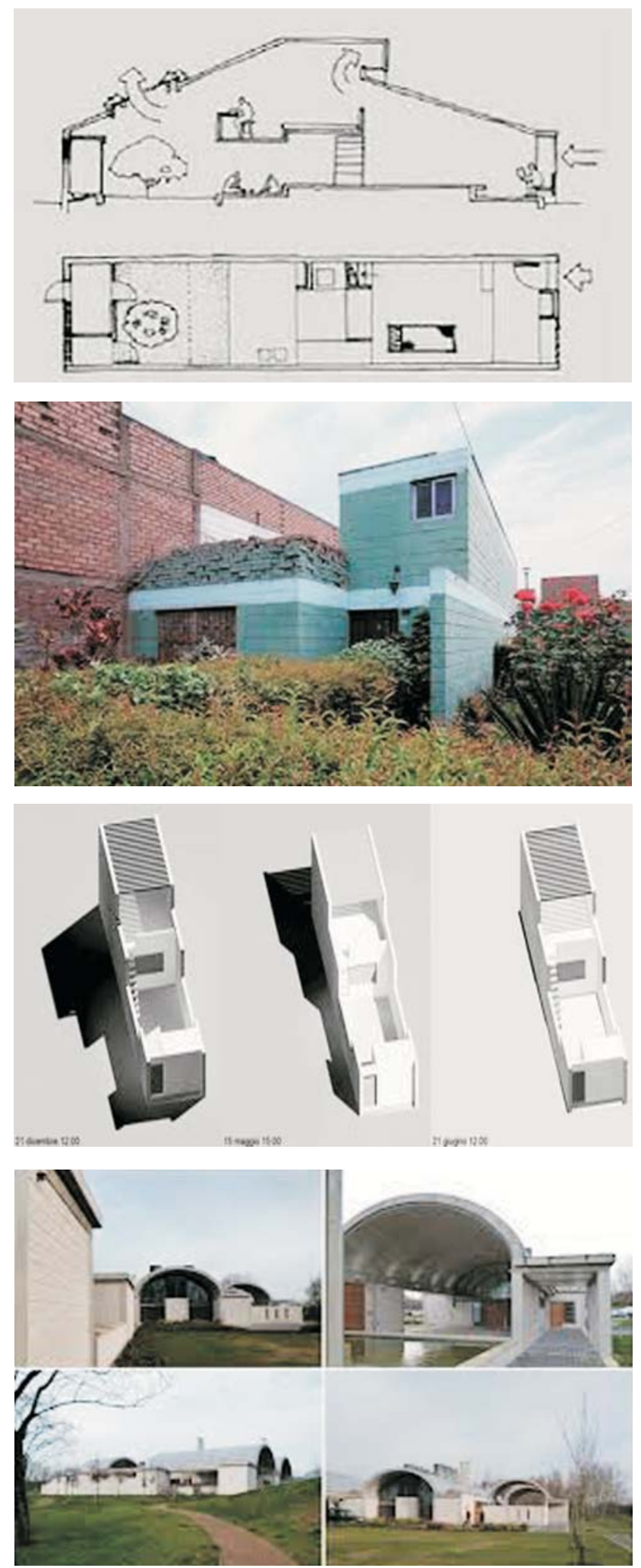

Figures 26-29: Tube houses by Charles Correa

Source: wwww.googlegeimages.com accessed 23-4-13 


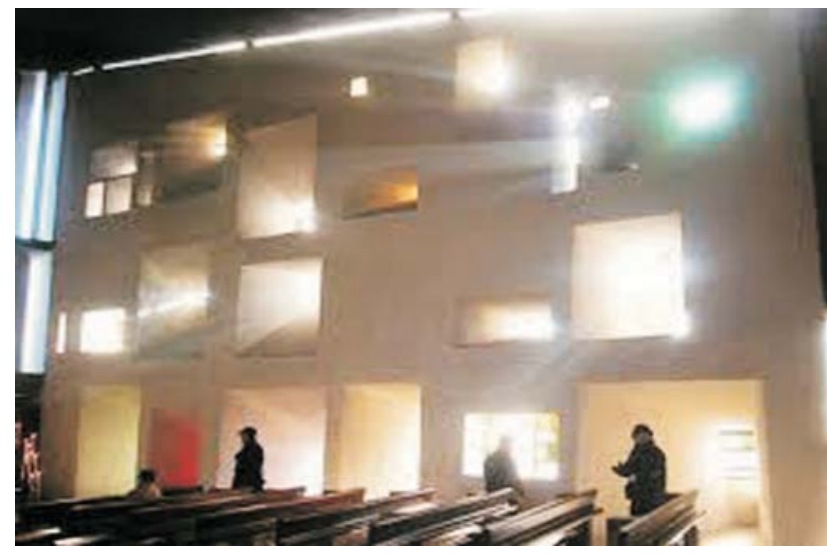

Figure 31: Ronchamp, France by Le-Corbusier

Source: wwww.googlegeimages.com accessed 23-4-13

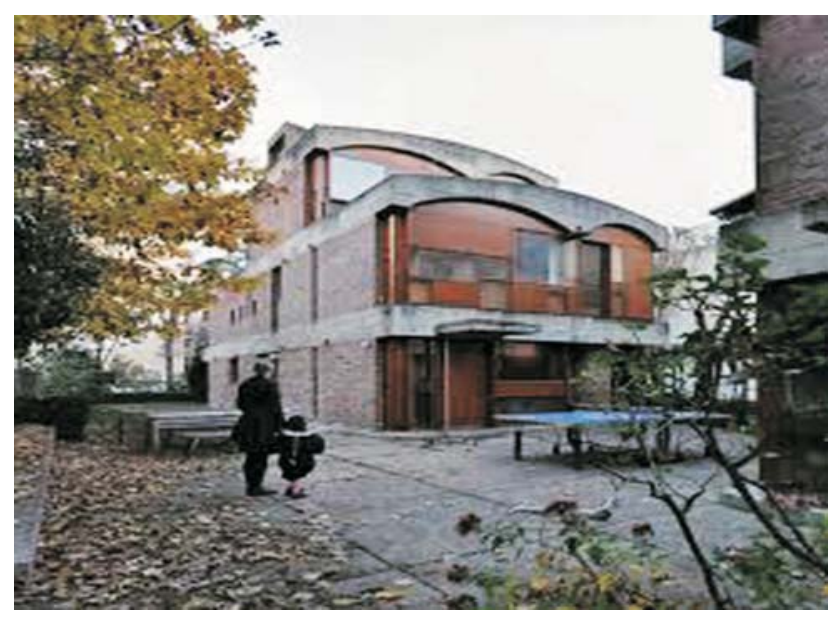

Figures 33-34: Jauol House, Paris France by Le-Corbusier Source: wwww.googlegeimages.com accessed 23-4-13
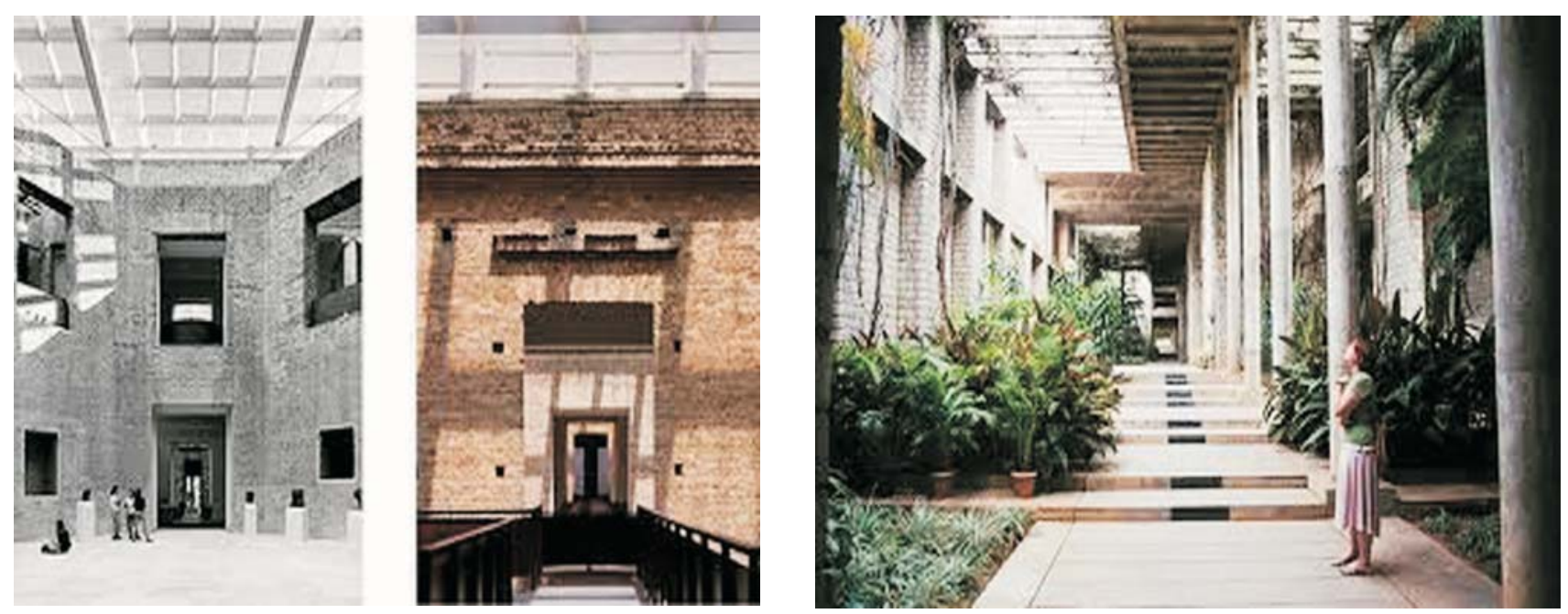

Figures 35-36: Indian Institute of Management, Bangalore, India by Doshi in India Source: wwww.googlegeimages.com accessed 16-4-13 
The Local Materials and Crafts Connection of the Built Form aith a Traditionalist and Vernacular Approach

Both Correa and Doshi promote the use of local materials and crafts and combine pre fabrication with local craft. According to the literature reviewed (Robson 2007 and 2002; Watson and Bentley, 2007,Powell, 1999; Belluardo, 1998; Frampton, 1997 and 1998; Curtis, 1988; Yeang, 1987; Abel, 1986; Correa, 1983) all these designers understand the vernacular of the region they are practicing in and are proficient in associating with the difference in scale and sophistication of vernacular and contemporary architecture. Although adopting principles of vernacular these designers never imitate vernacular architecture directly. Concepts derived through Hindu mythology and spirituality dominate the works of Correa and Doshi.

The literature reviewed also asserts that these designers have learnt how to use technically sound approaches through influences of the western architects like Le-Corbusier and Louis Kahn but have adopted these technological solutions to their local context (Figure 37). They have not imitated directly western technology or technical aspects of designs but have localised technology by creating a hybrid between the western ideas and local vernacular incorporating local craftsmen and their skill. As Curtis (1987:19) puts it 'Doshi had promised himself never to imitate Le Corbusier's brisessoleil (literally sub-breakers) directly, and the shading panels on his own house are really abstractions of Gujratijharokhasbalconies fitted out with ledges, screens and alcoves that project from the facades of wooden houses or stone temples.'

\section{The Economic Connection of the Built Form with a Place Making Approach}

Both Correa and Doshi have designed housing schemes where they have tried to address the requirements of local economy through mixed use housing, greater FAR (floor area ratio) and low cost infrastructure provisions. Correa have lobbied with the politicians to change underlying patterns of land use and emphasize equitable development. In their housing schemes both Correa and Doshi have proposed relaxation of land use controls to allow economic activities within low income households. In their housing schemes, which are a mix of low and high income houses, a certain number of houses are proposed as subsidised houses for low income households through open market sale of higher income houses. The subsidized houses are made available through allowing extra FAR on apartments sold in the open market as part of these schemes. Correa has also advocated the 'inventiveness with which squatters provide

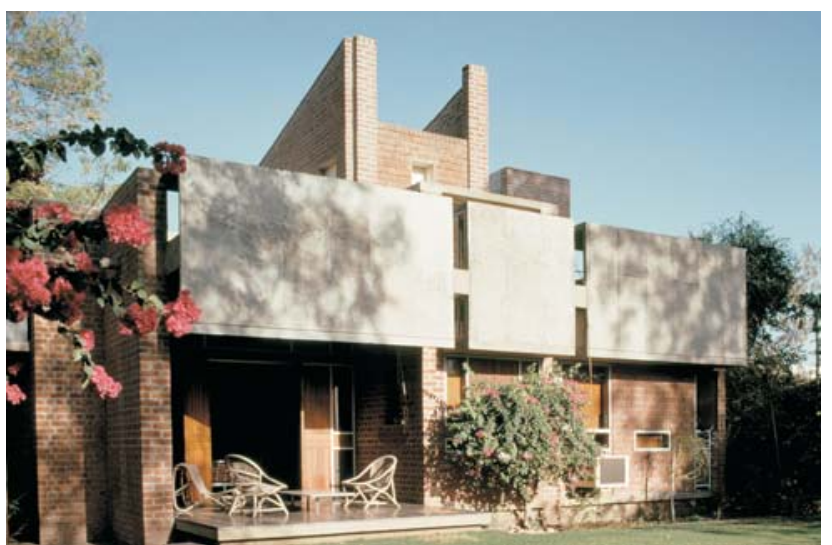

Figure 37: Doshi's own house making use of local materials and having a modern expression

Source: wwww.googlegeimages.com accessed 07-4-14

shelter for themselves' (Belluardo, 1998: 13) and have voiced the importance of localised solutions that promote local economics. Correa has advocated mixed use for low income housing schemes because according to him it's an economic and social requirement of people belonging to low income settlements (Chalana, 2010).

The Hawkers pavement project, Mumbai (1968) by Correa is a project which provides solutions to promote local economics. It recognises the intensive usage of pavements in the crowded centres of Indian cities by hawkers during the day and by residents of the locality during the night for sleeping. These residents are not necessarily pavement dwellers. They chose to sleep on the pavements as a respite from their stuffy, poorly ventilated and overcrowded shared rooms where their belongings are secured. Through this project Correa recommended to the municipal corporation to increase the width of the pavements in order to deal with the hawkers during the day and the pavement sleepers during the night, provide raised platforms and tap waters at regular intervals. The provision of platforms isolates the hawkers from the pedestrian traffic thus reduces chaos during the day and at night these platforms isolate the people sleeping on the platforms from the passer-by.

\section{SYNTHESIS- INDIAN ARCHITECTS}

If localness in the built form is defined as the incorporation of indigenous social and environmental values and processes into the built form within the contemporary global paradigm then both the architects discussed here have tried to achieve localness in the built form through addressing the social, economic and environmental requirements of the context and have tried to tie it up with the built form. They have 
attempted at understanding the local climate and socioeconomic requirements of the people of India and have produced form that respects the aspirations of the common man. The scale of intervention also varies from an architectural scale to an urban scale depending on the requirement of the project. The dimension of localness become indicators by addressing various design components as illustrated in table 1 :

Table 1: Summarising components of built form that have been addressed by Indian Architects (put together by author)

\begin{tabular}{|c|c|c|c|}
\hline $\begin{array}{l}\text { Component of } \\
\text { built form to } \\
\text { be addressed } \\
\text { for localness }\end{array}$ & $\begin{array}{l}\text { Elem ents of built form } \\
\text { addressed }\end{array}$ & $\begin{array}{l}\text { Scale of } \\
\text { built form } \\
\text { addressed }\end{array}$ & Salient Features \\
\hline $\begin{array}{l}\text { Urban } \\
\text { Morphology }\end{array}$ & $\begin{array}{l}\text { Plot, Building, In between } \\
\text { spaces }\end{array}$ & $\begin{array}{l}\text { Urban- } \\
\text { Physical }\end{array}$ & $\begin{array}{l}\text { Reflection of urban } \\
\text { planning at an architectural } \\
\text { scale respecting social } \\
\text { setups } \\
\text { Experimentation with } \\
\text { vertical master planning to } \\
\text { address shortage of land }\end{array}$ \\
\hline $\begin{array}{l}\text { Natural } \\
\text { resources }\end{array}$ & $\begin{array}{l}\text { Topography, Vegetation } \\
\text { Local use of space, Natural } \\
\text { elements: e.g. water }\end{array}$ & $\begin{array}{l}\text { Urban and } \\
\text { architectural- } \\
\text { Physical }\end{array}$ & $\begin{array}{l}\text { Incorporation of site } \\
\text { topography and existing } \\
\text { vegetation in design }\end{array}$ \\
\hline $\begin{array}{l}\text { Socially } \\
\text { responsive }\end{array}$ & $\begin{array}{l}\text { Introverted plans around } \\
\text { courtyards } \\
\text { Low rise high density housing } \\
\text { schemes } \\
\text { Shaded streets } \\
\text { Incremental devel opment } \\
\text { Mixed land use }\end{array}$ & $\begin{array}{l}\text { Urban and } \\
\text { architectural- } \\
\text { Physical } \\
\text {-Intangible }\end{array}$ & $\begin{array}{l}\text { Respecting the value, belief, } \\
\text { cultural and social systems }\end{array}$ \\
\hline $\begin{array}{l}\text { Climatically } \\
\text { responsive }\end{array}$ & $\begin{array}{l}\text { Recessed balconies, Screens } \\
\text { Over hangings, Eaves } \\
\text { Pergolas, Brises-soleil } \\
\text { Courtyards, Verandas }\end{array}$ & $\begin{array}{l}\text { Architectural } \\
\text { - Physical }\end{array}$ & $\begin{array}{l}\text { Keep the rain and sun out } \\
\text { and provide maximum cross } \\
\text { ventilation in humid and } \\
\text { arid climates } \\
\text { Passive cross ventilation } \\
\text { Landscape to surround built } \\
\text { forms }\end{array}$ \\
\hline $\begin{array}{l}\text { Local } \\
\text { materials, } \\
\text { technology and } \\
\text { crafts }\end{array}$ & $\begin{array}{l}\text { Promoting local crafts, } \\
\text { materials and technology }\end{array}$ & & $\begin{array}{l}\text { Learning from but not } \\
\text { duplicating local vernacular }\end{array}$ \\
\hline $\begin{array}{l}\text { Local } \\
\text { economy }\end{array}$ & $\begin{array}{l}\text { FAR, Mixed land use } \\
\text { Infrastructure devel opment }\end{array}$ & Urban & \\
\hline
\end{tabular}




\section{MALAYSIAN ARCHITECTS: KEN YEANG AND JIMMY LIM}

Malaysia also experienced colonisation during the late $18^{\text {th }}$ and early $19^{\text {th }}$ century. After independence in its search for an architectural language the Malaysian architects relied on the tropical climate and green landscape to develop characteristics of the built form.

\section{The Urban Connection of the Built Form with a Critical Regionalist Approach}

In Malaysia attempts at linking built form with urban morphology can be seen in the works of Ken Yeang. In his book entitled 'Tropical Verandah City'(1987) Ken Yeang, who started practice in 1971 and was influenced by modernist paradigm, uses the metaphor of a tropical urban garden and experiments with the idea of in-between spaces around a building (Powell, 1999). The Verandah City proposal is tied together by a 'system of arcaded pedestrian walkways that bind the buildings together. Such walkways could provide shelter and support street life, as with traditional shop houses' (Watson and Bentley, 2007: 189) (see Figures 38-39). 'Yeang looked at the permeable edges of traditional tropical buildings and the layering of facades and concluded that the edges of a tropical building by virtue of their many layers becomes softer' (Powell 1999). This led to the generation of the idea of an ecologically responsive urban design. Later in his career the concepts of 'green skyscrapers' extends to the concept of the vertical city which he presented in an expo in 2005 and looked at vertical master plans (Powell 1999). The 'soft edge aesthetics' was also introduced by him where the edges of towers had spaces for planters and landscape to soften the periphery of the mass and acted as environmental filters (Powell 1999) (see Figures 40-43). Having written on the concept of regional architecture Yeang believes that 'regional urban architecture should embody a sense of continuity and place' and stresses abstract and direct links between architecture and cultural heritage (Powell 1999).

Thus for Yeang the local connection comes from an understanding and designing of the left over spaces in between buildings and the streets which he calls 'edges' and he connects to the users at a local level through design of spaces like the arcaded pedestrian walkways.

\section{The Social Connection of the Built Form with a Place Making Approach}

Architect Jimmy Lim, in Malaysia, has also developed housing options which stem from an understanding of the
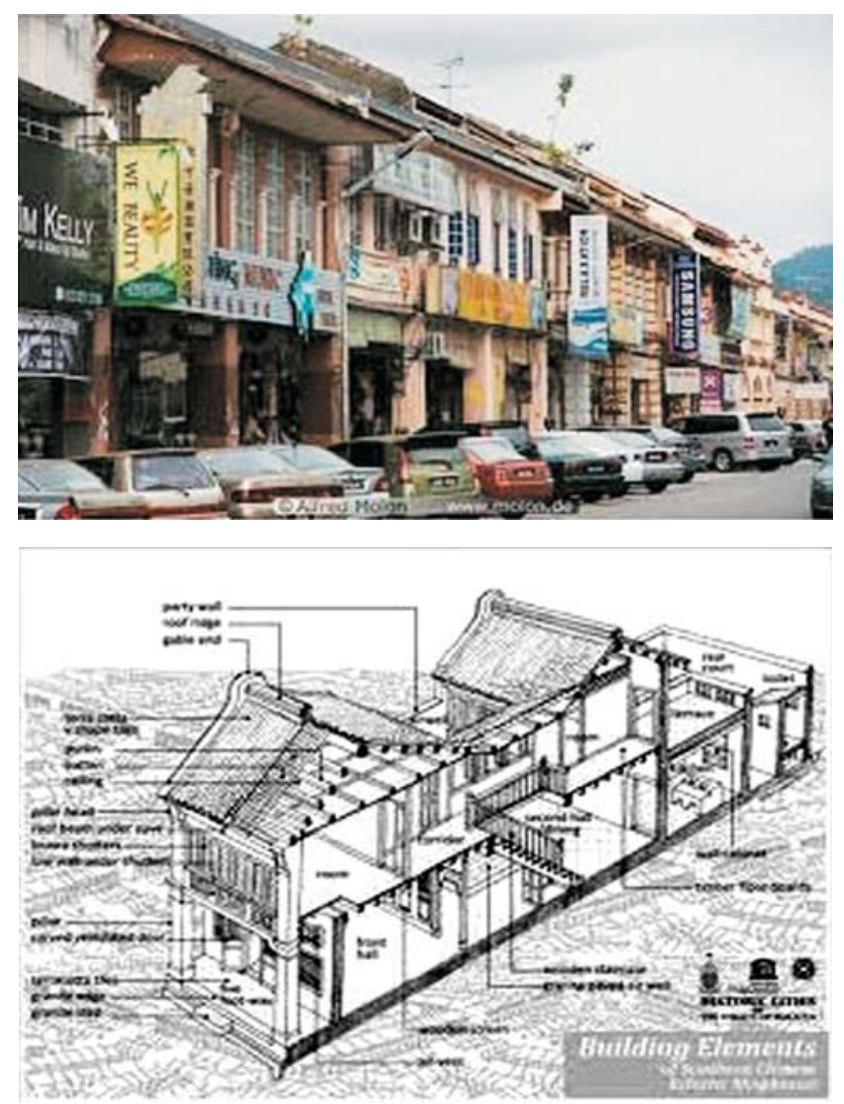

Figures 38-39: Images of shop houses in Malaysia Source: wwww.googlegeimages.com accessed 23-4-13

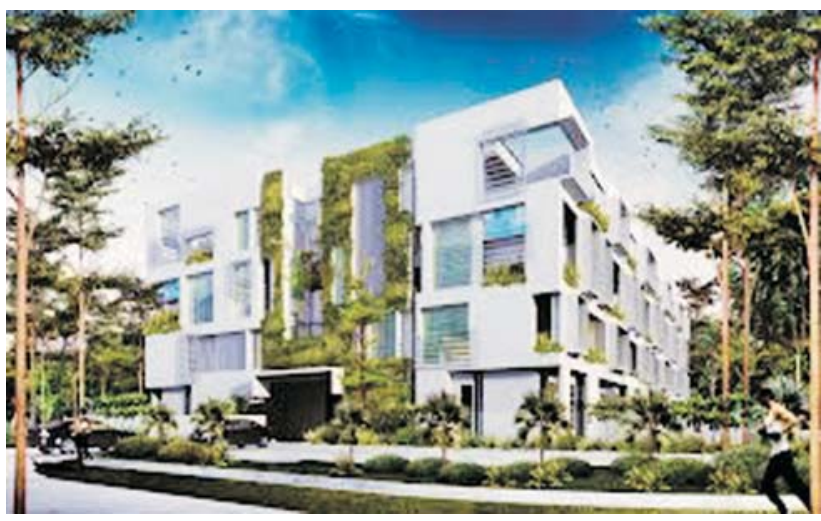

Figure 40: Some design projects by Ken Yeang, Malaysia Source: wwww.googlegeimages.com accessed 16-4-13

social context. He has developed a contemporary interpretation of the traditional timber Malay house which reflects the socio-cultural aspects of both traditional and modern Malaysian built form (Watson and Bentley, 2007). Lim strongly believes in the conservation and restoration of the shop houses of Malaysia in the dense urban fabric and is exploring the idea of 'Kampungminium' which is a 

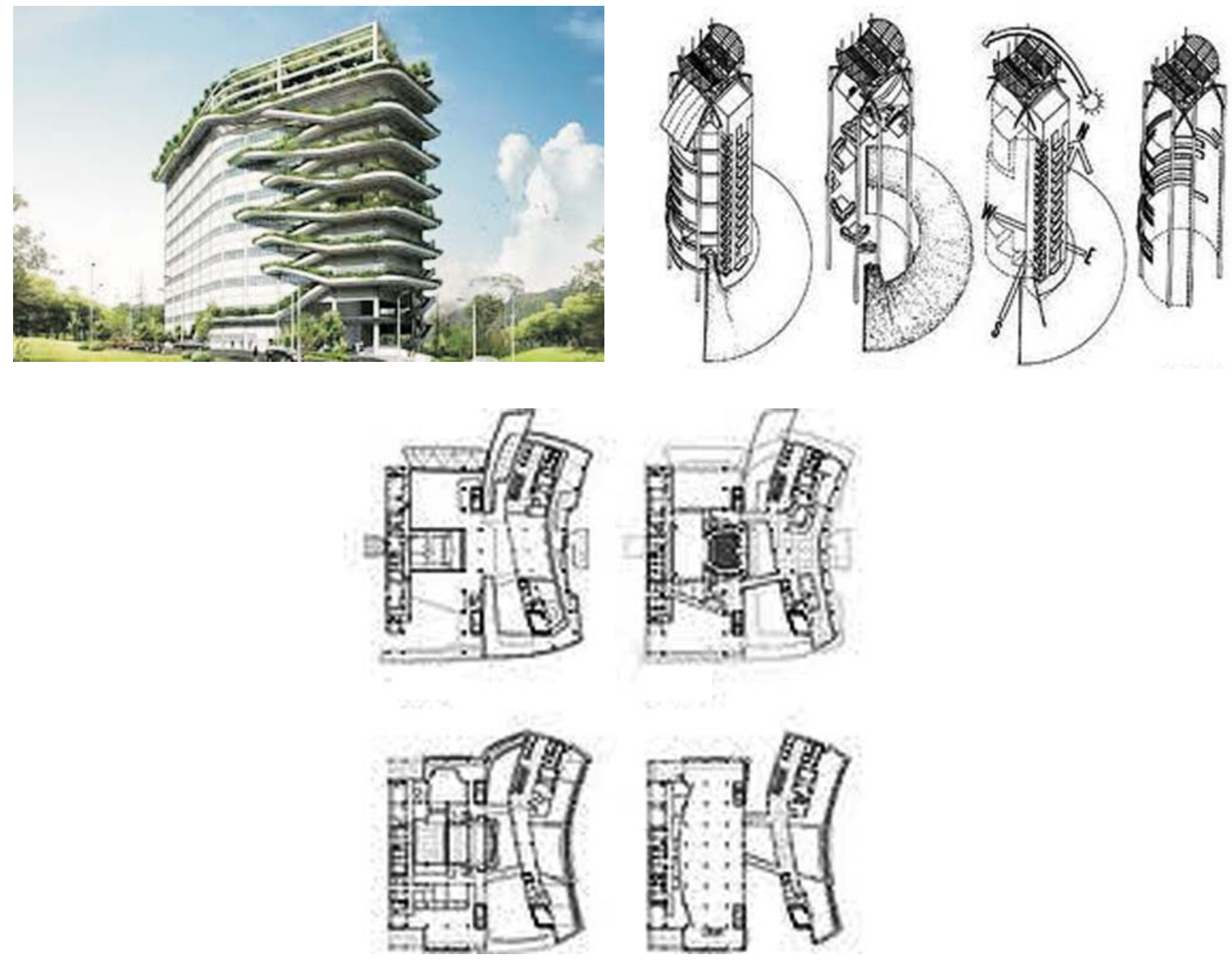

Figures 41-43: Some design projects by Ken Yeang, Malaysia Source: wwww.googlegeimages.com accessed 16-4-13

fusion of 'a traditional Malay Kampong development, a shop house and a modern condominium' and aims to provide a modern language for the built form and remain local at the same time through conserving the traditional shop houses and Malay Kampong development (Watson and Bentley, 2007:204). He hopes that this hybrid form will be able to convince the developers to retain the existing urban landscape and built within and around it retaining the original characteristics of place.

\section{The Natural Connection of the Built Form with a Regionalist Approach}

The design vocabulary of Malaysian contemporary architect and architectural theorist, Jimmy Lim while respecting the natural settings of a context also takes reference from it to produce designs which are modern yet rooted in the local context. According to Watson and Bentley, (2007:192) his design principles are based on "climatic factors, environmental influences, cultural and traditional influences, traditional structural concepts and spiritual metaphors'. In cities where rapid urban growth generate images associated with global economy and overrun the indigenous qualities of the built form Jimmy Lim's design strategies levying on the landscape of the context to infuse back some of this regionalism. Malaysia has a strong geography and thus a pre dominant landscape (Watson and Bentley, 2007). Respecting the importance of water Lim gives consideration to both surface and subterranean water usage as according to his believes it has implications for 'energy, luck and continuity' (Watson and Bentley, 2007: 192). In his own house he has devised a method to collect the discharged water into a large container 
to be used to irrigate trees. He also uses the adjacent plot to grow local trees and plants which he replants in his new design projects, which according to him is his way of compensating for what the construction activity takes away from the land. He believes in maintain a 'yin-yang' relationship with land and in preserving the natural balance (Watson and Bentley, 2007: 192).

Ken Yeang, in Malaysia has also explored the concepts of natural ventilation through his designs of Bio-climatic sky scrapers. According to the literature reviewed he incorporated climatically adequate responses to high rise buildings in Malaysia based on principles of natural ventilation, filtered sunlight and climatically responsive space planning. Thus in the creation of micro climate within the high rise buildings using spaces like open to sky courtyards, sky courts, stepped planter-boxes and shaded projecting terraces he was working towards developing a architecture of Malaysia which was modern yet it returned to the cultural and historical sources derived from within the context (Powell, 1999).

\section{SYNTHESIS- MALAYSIAN ARCHITECTS}

For the Malaysian architects the climatically responsive architecture addressing natural resources came as a priority. They however, also explored urban morphological components through exploration of hybrid forms of shop houses and the bio climatic skyscrapers (see Figures 44-46). The scale of intervention also varies from an architectural scale to an urban scale.
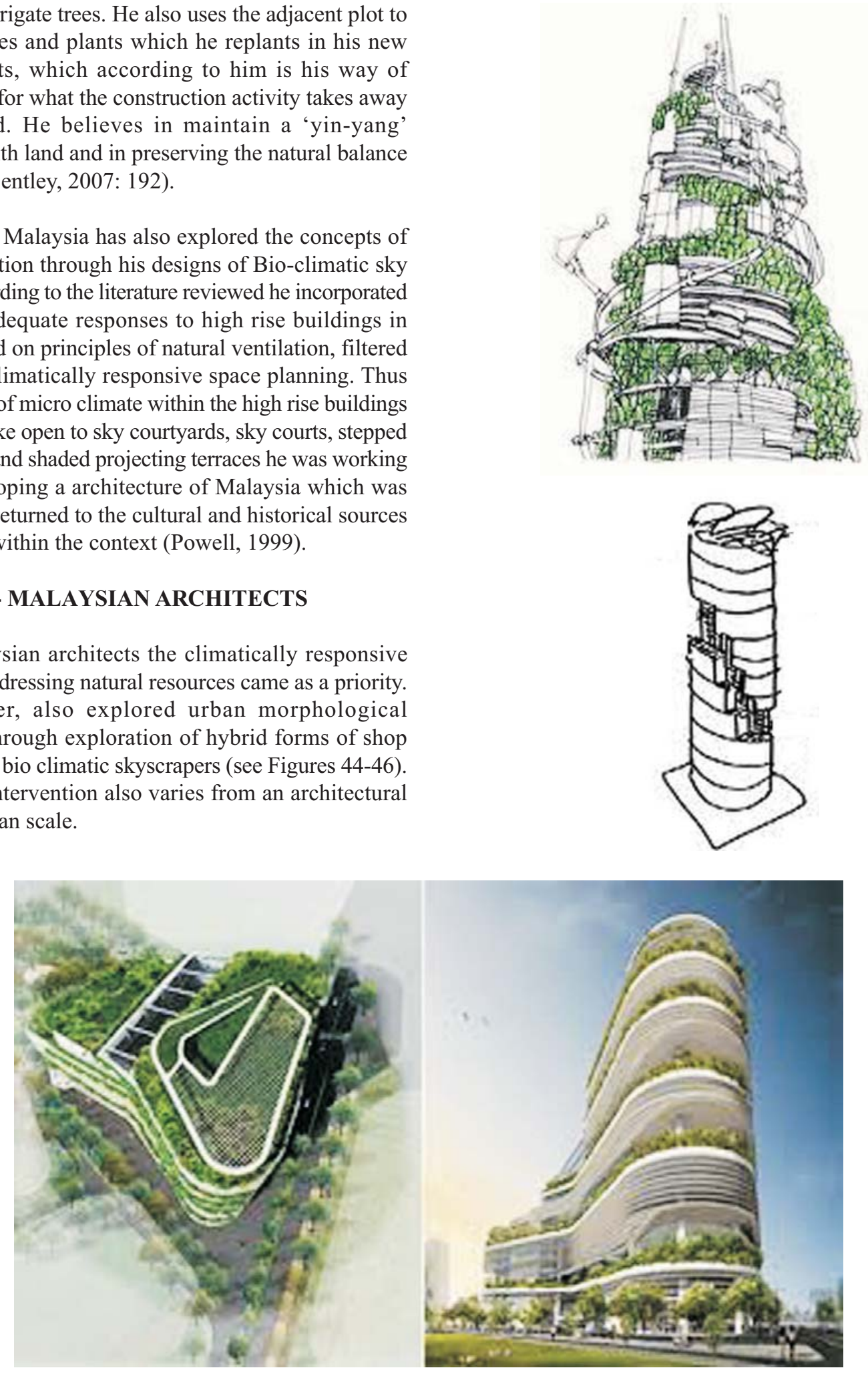

Figures 44-46: Bio climatic sky scrapers by Ken Yeang, Malaysia Source: wwww.googlegeimages.com accessed 16-4-13 
The dimension of localness become indicators by addressing various design components as illustrated in the table 2 :

Table 2: Summarising components of built form that have been addressed by Malaysian Architects (put together by author)

\begin{tabular}{|c|c|c|c|}
\hline $\begin{array}{l}\text { Component of } \\
\text { built form to } \\
\text { be addressed } \\
\text { for localness }\end{array}$ & $\begin{array}{l}\text { Elem ents of built form } \\
\text { addressed }\end{array}$ & $\begin{array}{l}\text { Scale of } \\
\text { built form } \\
\text { addressed }\end{array}$ & Salient Features \\
\hline $\begin{array}{l}\text { Urban } \\
\text { Morphology }\end{array}$ & $\begin{array}{l}\text { Plot, Building, In between } \\
\text { spaces }\end{array}$ & $\begin{array}{l}\text { Urban- } \\
\text { Physical }\end{array}$ & $\begin{array}{l}\text { Reflection of urban planning } \\
\text { at an architectural scale } \\
\text { respecting social setups } \\
\text { Experimentation with } \\
\text { vertical master planning to } \\
\text { address shortage of land }\end{array}$ \\
\hline \begin{tabular}{|l|} 
Natural \\
resources
\end{tabular} & $\begin{array}{l}\text { Topography, Vegetation } \\
\text { Local use of space, Natural } \\
\text { elements: e.g. water }\end{array}$ & $\begin{array}{l}\text { Urban and } \\
\text { architectural } \\
\text { - Physical }\end{array}$ & $\begin{array}{l}\text { Incorporation of site } \\
\text { topography and existing } \\
\text { vegetation in design }\end{array}$ \\
\hline $\begin{array}{l}\text { Socially } \\
\text { responsive }\end{array}$ & $\begin{array}{l}\text { High rise high density housing } \\
\text { schemes } \\
\text { Shaded streets } \\
\text { Mixed land use }\end{array}$ & $\begin{array}{l}\text { Urban and } \\
\text { architectural } \\
\text { - Physical } \\
+ \\
\text {-Intangible }\end{array}$ & $\begin{array}{l}\text { Respecting the value, belief, } \\
\text { cultural and social systems }\end{array}$ \\
\hline $\begin{array}{l}\text { Climatically } \\
\text { responsive }\end{array}$ & $\begin{array}{l}\text { Natural ventilation, filtered } \\
\text { sunlight, Open to sky } \\
\text { courtyards, sky courts, stepped } \\
\text { planter-boxes, } \\
\text { projecting terraces }\end{array}$ & $\begin{array}{l}\text { Architectura } \\
\text { 1-Physical }\end{array}$ & $\begin{array}{l}\text { Keep the rain and sun out } \\
\text { and provide maximum cross } \\
\text { ventilation in humid climate } \\
\text { Passive cross ventilation } \\
\text { Landscape to surround built } \\
\text { forms }\end{array}$ \\
\hline
\end{tabular}

\section{CONCLUSION}

It can be concluded that each of the architects briefly reviewed here have developed design strategies based on local culture, climate and social and economic values which might have enabled them to produce built form that not only respects the physical context but also offer local cultural and social solutions. Thus the intangible aspects like social values and cultural practices of a context become as important as the physical aspects of the built form. The design strategies employed by the above mentioned architects also highlight the importance of understanding and adopting the vernacular solutions offered by a context in order to achieve localness of the built form. The scale of involvement fluctuates between urban and architectural scale.

As summarised in the table above it can also be concluded that the theories on critical regionalism and regionalism mainly deal with dominant built form, theories on place making are mainly concerned with sprawling built form and theories on traditional and vernacular architecture focus on peripheral built form. 
Table 3 highlights the typology of built form addressed by these architects and tries to tie in the typology with the larger theories and components of built form.

Table 3: Typology of built form addressed within larger theories and components of built form (put together by author)

\begin{tabular}{|c|c|c|c|c|c|c|c|}
\hline & Components 0 & built for & that are ol & erationalized & within theo & ies & \\
\hline $\begin{array}{l}\text { Larger } \\
\text { Theory }\end{array}$ & $\begin{array}{l}\text { Built form to } \\
\text { respect urban } \\
\text { morphological } \\
\text { evolution }\end{array}$ & $\begin{array}{l}\text { Built } \\
\text { form to } \\
\text { be } \\
\text { socially } \\
\text { responsi } \\
\text { ve }\end{array}$ & $\begin{array}{l}\text { Built form } \\
\text { to respect } \\
\text { natural } \\
\text { resources }\end{array}$ & $\begin{array}{l}\text { Built form } \\
\text { to be } \\
\text { climatically } \\
\text { responsive }\end{array}$ & $\begin{array}{l}\text { Built form } \\
\text { to be } \\
\text { responsive } \\
\text { to local } \\
\text { materials, } \\
\text { technology } \\
\text { and crafts }\end{array}$ & $\begin{array}{l}\text { Built form } \\
\text { to be } \\
\text { responsive } \\
\text { to local } \\
\text { economy }\end{array}$ & $\begin{array}{l}\text { Built } \\
\text { form to } \\
\text { have } \\
\text { flexibility }\end{array}$ \\
\hline $\begin{array}{l}\text { Critical } \\
\text { Regionalism }\end{array}$ & & & & & & & \\
\hline Regionalism & & & & & & & \\
\hline $\begin{array}{l}\text { Place } \\
\text { making/ } \\
\text { Place } \\
\text { identity }\end{array}$ & & & & & & & \\
\hline $\begin{array}{l}\text { Traditional } \\
\text { Architecture }\end{array}$ & & & & & & & \\
\hline $\begin{array}{l}\text { Vernacular } \\
\text { Architecture }\end{array}$ & & & & & & & \\
\hline & & & & & & \multicolumn{2}{|c|}{$\begin{array}{l}\text { Dominant built form } \\
\text { Sprawling built form } \\
\text { Peripheral built form }\end{array}$} \\
\hline
\end{tabular}

\section{REFERENCES}

Abel, C. (2000). Architecture and Identity: responses to cultural and technological change. Oxford, Architectural Press.

Abel, C. (1986). "Regional Transformations." Architectural Review 180(1077): 37-43.

Alexander, C., S. Ishikawa, et al. (1977). A pattern language: towns, buildings, construction. Oxford, Oxford university press.

Asquith, L. and M. Vellinga, Eds. (2006). Vernacular Architecture in the Twenty-First Century: Theory, education and practice. London and New York, Taylor \& Francis Group.

Belluardo, J. (1998). The architecture of Kavinde, Doshi and Correa in political and social context. An architecture of independence: the making of modern South Asia: Charles Correa, Balkrishna Doshi, Muzharul Islam, Achyut Kanvinde. New York, Architectural League of New York.

Chalana, M. (2010). "Slumdogs vs. millionaires: balancing urban informality and global modernity in Mumbai, India." Journal of architectural education 63(2): 25-37.

Correa, C. (1983). Quest for Identity. Architecture and Identity: Exploring Architecture in Islamic Cultures 1, Kuala Lumpur, The Aga Khan Award for Architecture Concept Media Pte Ltd. 
Curtis, W. J. R. (1987). Balkrishna Doshi: An Architecture for India. New York, Rizzoli.

Frampton, K. (1983). Towards a Critical Regionalism: Six Points an Architecture of Resistance. The Anti-Aesthetic. Essays on Postmodern Culture H. Foster. Seattle, Bay Press.

Frampton, K., C. Correa, et al. (1997). Charles Correa. London, Thames \& Hudson.

Jacobs, J. (1961). The death and life of great American cities. New York, Random

Jencks, C. (2007). Critical Modernism: where is post-modernism going? London, John Wiley \& Sons.

King, A. D. (2004). Spaces of global cultures: architecture urbanism identity. London, Routledge.

Knox, P. (2011). Cities and Design. London, Routledge.

Lynch, K. (1972). What Time is this Place? Massachusetts, MIT Press

Oliver, P. (1997). Encyclopaedia of vernacular architecture of the world, Volume 1, Theories and principles. Cambridge, Cambridge University Press 1.

Powell, R. (1999). Rethinking the skyscraper: The complete Architecture of Ken Yeang. London, Thames \& Hudson.

Relph, E. (1976). Place and Placelessness. London, Pion Limited.

Relph, E. (1987). The modern urban landscape. London and Sydney, Croom Helm.

Ricouer, P. (1983). Towards a Critical Regionalism: Six Points for an Architecture of Resistance. The Anti-Aesthetic. Essays on Postmodern Culture F. Hall. Seattle., Bay Press: 16-30.

Robson, D. (2002). Bawa: Geoffrey Bawa: the complete works. London, Thames \& Hudson.

Robson, D. (2007). Beyond Bawa: Modern Masters of Monsoon Asia. London, Thames \& Hudson.

Sassen, S. (2001).The global city; introducing a concept and its history. S, M, X, XL. J. Sigler eds. Rotterdam, Monacelli Press

Tzonis, A. and L. Lefaivre (2012).Architecture of Regionalism in the age of Globalization. London \& New York, Routledge.

Unwin, S. (2009). Analysing Architecture. London and New York, Routledge.

Vale, L. J. (1992). Architecture, Power and National Identity. London, Yale University Press.

Watson, G. B. and I. Bentley (2007).Identity by Design. Amsterdam, Elsevier.

Yeang, K. (1987). The tropical verandah city: Some urban design ideas for Kuala Lumpur. Petaling Jaya, Selangor Darul Ehsan ., Longman. 